\title{
Inhibition of Human Endothelial Cell Proliferation in Vitro and Neovascularization In Vivo by D-Penicillamine
}

Tsukasa Matsubara, Ryuichi Saura, Kazushi Hirohata, and Morris Ziff*

Department of Orthopedic Surgery, Kobe University School of Medicine, Kobe, Japan; and *The Harold C. Simmons Arthritis

Research Center and the Department of Internal Medicine (Inflammation Research Unit), The University of Texas

Southwestern Medical Center at Dallas, Southwestern Medical School, Dallas, TX 75235-9069

\section{Abstract}

To investigate the effects of D-penicillamine (D-Pen) on angiogenesis, we have studied the effects of this drug on in vitro proliferation of human endothelial cells (EC) and in vivo corneal neovascularization. D-Pen, in the presence of copper sulfate, suppressed tritiated thymidine $\left(\left[{ }^{3} \mathrm{H}\right] \mathrm{TdR}\right)$ incorporation into $\mathrm{EC}$ in a dose-dependent manner. Significant inhibition was observed with D-Pen concentrations attainable in the serum and tissues of treated patients. Neither D-Pen nor copper ion alone significantly affected $\left[{ }^{3} \mathrm{H}\right] \mathrm{TdR}$ incorporation into EC. The inhibition by D-Pen and copper was blocked by catalase (CAT) or horseradish peroxidase but not by boiled CAT or SOD. When rabbits were daily injected intravenously with D-Pen at the per kilogram dosage administered to rheumatoid patients, neovascularization as quantitated by the proliferation of corneal new blood vessels was significantly inhibited. These results suggest that hydrogen peroxide generated by D-Pen and copper exerts a pronounced antiangiogenic effect through inhibition of EC proliferation. It is, therefore, considered that D-Pen may suppress rheumatoid synovitis by reducing the number of small blood vessels available for the emigration of chronic inflammatory cells, and the proliferation of the synovial tissue.

\section{Introduction}

Neovascularization, the generation of new blood vessels, is required not only in such normal phenomena as wound repair and embryonic development but also in such pathological conditions as tumor growth, proliferation of connective tissue, chronic inflammation, and certain immune reactions (1). The rheumatoid synovial membrane is characterized by prominent infiltration of mononuclear cells in the sublining region of the synovium. These cells carry out a series of cellular and humoral immune reactions that are responsible for the maintenance and spread of rheumatoid synovitis (2). Inherent in this process is an active proliferation of small blood vessels that are required for the extensive emigration of mononuclear cells and proliferation of the synovial tissues, which are characteristic of this type of synovitis. Proliferation of small blood vessels is

Address reprint requests to Dr. Tsukasa Matsubara, Department of Orthopedic surgery, Kobe University School of Medicine, 7 Chome Kusunoki-cho, Chuo-ku, Kobe, Japan. 1988

Received for publication 2 May 1988 and in revised form 11 August

J. Clin. Invest.

(C) The American Society for Clinical Investigation, Inc.

$0021-9738 / 89 / 01 / 0158 / 10 \$ 2.00$

Volume 83, January 1989, 158-167 critically dependent on the local proliferation of endothelial cells (EC) (1). In contrast to infiltrating mononuclear cells like the macrophage, which is derived from bone marrow, there is no distant reservoir to supply an increased demand for EC by the proliferating vessels of the rheumatoid synovium. Inhibition of EC proliferation, therefore, would have the potential to slow or diminish immunologically mediated rheumatoid inflammation. Because EC may participate in immunological reactions by presenting antigen to $\mathrm{T}$ and $\mathrm{B}$ lymphocytes (3-5) with expression of histocompatibility (Ia) antigen (6), and by secreting IL $1(7,8)$, a decrease in the EC population may diminish synovial inflammation by also affecting these processes.

D-Penicillamine (D-Pen $)^{1}$ has been reported to improve the symptoms of RA and to bring about clinical remission (9-13). Although a variety of actions of this drug have been reported to be responsible for its therapeutic efficacy (14-22), the mechanism underlying its beneficial effects has not been adequately explained. To investigate the possible effects of D-Pen on angiogenesis, we have studied the action of this drug on basal and endothelial cell growth factor (ECGF)-stimulated proliferation of human umbilical vein EC, and also on ECGF-induced neovascularization in vivo. It has been shown that the concentrations of D-Pen, which are attained in the serum and synovial tissue of treated patients, inhibit EC proliferation and neovascularization.

\section{Methods}

Preparation of human EC and EC monolayers. EC were obtained from human umbilical veins as described previously with some modifications (23). Fresh umbilical cords were placed in HBSS (Gibco Laboratories, Grand Island, NY). The umbilical veins were cannulated and perfused with HBSS to wash out the residual blood. Both ends of the cord were clamped and then infused with $1 \%$ collagenase (Worthington Biochemicals, Freehold, NJ) in RPMI 1640 (Gibco Laboratories) for $15 \mathrm{~min}$ at room temperature. The collagenase solution containing detached EC was flushed out of the cord with RPMI 1640. The cells were then centrifuged and resuspended in complete medium, i.e., RPMI 1640 containing 15\% heat-inactivated FCS (Gibco Laboratories), $10 \%$ heat-inactivated human serum, $25 \mu \mathrm{g} / \mathrm{ml} \mathrm{ECGF}$ (Collaborative Research, Lexington, MA), $5 \mathrm{U} / \mathrm{ml}$ heparin sodium (Upjohn, Kalamazoo, MI), and antibiotics. EC were cultured overnight in 25- $\mathrm{cm}^{2}$ tissue culture flasks (Corning Glass Works, Corning, NY) at $37^{\circ} \mathrm{C}$ in a $\mathrm{CO}_{2}$ incubator $\left(5 \% \mathrm{CO}_{2}, 95 \%\right.$ air). The next day, nonadherent cells were vigorously rinsed from the flasks and fresh complete medium was added. When the primary cultures reached confluency, EC were trypsinized, resuspended in complete medium, and seeded

1. Abbreviations used in this paper: CAT, catalase; D-Pen, D-penicillamine; EC, endothelial cell; ECGF, endothelial cell growth factor; GST, gold sodium thiomalate; HRPO, horseradish peroxidase; TdR, thymidine. 
into three gelatin-coated flasks for further passage. EC obtained in this way were used in the third or fourth passage for the experiments described below. The identity of the EC was established by their characteristic morphology under phase-contrast microscopy and by indirect immunofluorescence when stained with a rabbit anti-Factor VIII antiserum (Cappel Laboratories, Cochranville, PA). All cells were positively stained. The percent of cells staining positively with the antimacrophage antibody 63D3 (24) by FACS analysis was $<1 \%$. All individual batches of EC were prepared from single umbilical cords. EC were detached from confluent monolayers by trypsinization and further cultures were carried out in sterile, gelatin-coated, flat-bottomed microtiter wells $(6.4 \mathrm{~mm}$ diameter) (Corning Glass Works). Each well contained $2 \times 10^{4} \mathrm{EC}$ in $0.2 \mathrm{ml}$ culture medium, consisting of RPMI 1640 containing 5\% heat-inactivated FCS and antibiotics. This medium was used in all EC proliferation assays unless otherwise stated. After the microtiter wells were placed in a $\mathrm{CO}_{2}$ incubator for 3-4 $\mathrm{h}$ to obtain subconfluent EC monolayers, the assays for EC proliferation were started.

Tritiated thymidine $\left.\left({ }^{3} H\right] T d R\right)$ incorporation into EC. Cultures were carried out in the presence or absence of various concentrations of ECGF for $48 \mathrm{~h}$. $15 \mathrm{~h}$ before harvesting, we added $1 \mu \mathrm{Ci}$ of $\left[{ }^{3} \mathrm{H}\right] \mathrm{TdR}$ to each well. At the incubation period, EC were washed three times with 0.05 M PBS (pH 7.4) and detached from the microtiter wells by trypsinization. Detached EC were harvested onto glass fiber filter paper using a mini-MASH II microharvesting device (Whittaker MA Bioproducts, Walkersville, MD) and $\left[{ }^{3} \mathrm{H}\right] \mathrm{TdR}$ incorporated into EC (cellassociated $\left[{ }^{3} \mathrm{H}\right] \mathrm{TdR}$ ) was determined using a liquid scintillation counter.

Effects of p-penicillamine, other thiols, or disulfides on $\left[{ }^{3} H\right] T d R$ incorporation into EC in the presence or absence of copper sulfate. Cultures were done in the presence or absence of ECGF, and simultaneously, with and without various concentrations of D-Pen (Sigma Chemical Co., St. Louis, MO) and copper sulfate (Sigma Chemical Co.). To study the effects of other thiols such as D-cysteine, L-cysteine, DL-cysteine, thiomalic acid, 2-mercaptoethanol, DTT, and reduced glutathione, or disulfides such as oxidized D-Pen and oxidized glutathione (all obtained from Sigma Chemical Co.) these agents were substituted for D-Pen. $\left[{ }^{3} \mathrm{H}\right] \mathrm{TdR}$ incorporated into EC was counted as described above. Time-dependent effects of D-Pen on the DNA synthesis of EC were measured in two ways. First, EC were cultured with or without ECGF in the presence of D-Pen and copper sulfate for increasing time periods up to $48 \mathrm{~h}$. The EC in the microtiter wells were then washed with culture medium to remove extracellular D-Pen and copper sulfate. Fresh culture medium, with or without ECGF, was then added to the wells and the culture continued. Incorporation of $\left[{ }^{3} \mathrm{H}\right] \mathrm{TdR}$, added $15 \mathrm{~h}$ before harvesting, was measured $48 \mathrm{~h}$ after initiation of the cultures. Second, to examine the effect of D-Pen and copper sulfate on any given phase of EC proliferation, these agents were added to the EC cultures at the initiation of incubation or at varying times thereafter and $\left[{ }^{3} \mathrm{H}\right] \mathrm{TdR}$ incorporation was measured $48 \mathrm{~h}$ after the initiation of the culture.

$\left[{ }^{3} H\right] T d R$ incorporation into human fibroblasts. Primary cultures of fibroblasts were established from explants of human foreskins by a standard technique. Fibroblasts in their fifth to tenth subpassage were harvested from stock cultures by trypsinization and suspended in RPMI 1640 supplemented with $10 \%$ FCS and antibiotics. $\left[{ }^{3} \mathrm{H}\right] \mathrm{TdR}$ incorporation into the cells with or without stimulation by IL 1 was measured as described previously with slight modifications (25). 1 $\times 10^{4}$ fibroblasts in $0.2 \mathrm{ml}$ culture medium were cultured in flat-bottomed microtiter wells (Corning Glass Works) and $1 \mathrm{U} / \mathrm{ml}$ ultrapure IL 1 (Whatman Inc., Clifton, NJ) was added to the cultures in the presence or absence of varying concentrations of $\mathrm{D}$-Pen and copper sulfate. The total time of the assay was $72 \mathrm{~h} .1 \mu \mathrm{Ci}$ of $\left[{ }^{3} \mathrm{H}\right] \mathrm{TdR}$ was added to the cultures $15 \mathrm{~h}$ before harvesting and $\left[{ }^{3} \mathrm{H}\right] \mathrm{TdR}$ incorporation was measured as described above.

$\left[{ }^{3} H\right] T d R$ incorporation into PBMC. PBMC were obtained by centrifuging venous blood taken from healthy human donors on Ficoll Hypaque (Pharmacia Fine Chemicals, Piscataway, NJ) as previously described (26). PBMC were then suspended in RPMI 1640 containing $10 \%$ FCS and antibiotics. $1 \times 10^{5}$ PBMC, in $0.2 \mathrm{ml}$ of the culture medium, were then placed in round-bottomed microtiter wells (Corning Glass Works). Cultures were then carried out in the presence of 5 $\mu \mathrm{g} / \mathrm{ml}$ Con A (Sigma Chemical Co.) or $0.5 \mu \mathrm{g} / \mathrm{ml}$ PHA (Sigma Chemical Co.) in the presence of varying concentrations of D-Pen and copper sulfate. $15 \mathrm{~h}$ before harvesting, $1 \mu \mathrm{Ci}$ of $\left[{ }^{3} \mathrm{H}\right] \mathrm{TdR}$ was added to each well. The total duration of the cultures was $72 \mathrm{~h}$. The cells were then harvested onto glass fiber filter paper and incorporated $\left[{ }^{3} \mathrm{H}\right] \mathrm{TdR}$ was counted as described above.

Effects of catalase (CAT), horseradish peroxidase (HRPO), boiled $C A T$ and SOD on inhibition of EC DNA synthesis by D-Pen (or other thiols) plus copper sulfate or by hydrogen peroxide $\left(\mathrm{H}_{2} \mathrm{O}_{2}\right)$. ECGFstimulated and -unstimulated EC were cultured with or without D-Pen or other thiols in the presence of copper sulfate. To the D-Pen and copper containing wells, CAT, boiled CAT, HRPO, or SOD (all from Sigma Chemical Co.) were added at the initiation of culture. $\left[{ }^{3} \mathrm{H}\right] \mathrm{TdR}$ uptake by the EC was assayed. Boiled CAT was obtained as previously described (27). To study the effect of $\mathrm{H}_{2} \mathrm{O}_{2}$ (Sigma Chemical Co.) on $\left[{ }^{3} \mathrm{H}\right] \mathrm{TdR}$ incorporation, EC were cultured in the presence of $\mathrm{H}_{2} \mathrm{O}_{2}$, simultaneously with or without the enzymes listed above.

Inhibition of corneal neovascularization by D-Pen. ECGF-containing sterile polymer pellets were made as described previously with slight modifications (28). $5 \mathrm{mg}$ of ECGF was diluted in hydroxyethylmethacrylate (Polysciences, Inc., Warrington, MA) in $70 \%$ alcohol at $37^{\circ} \mathrm{C}$. This solution was dried under a mild vacuum overnight, leaving the ECGF trapped within the polymer matrix. The ECGF pellet, 1 $\times 1 \times 0.5 \mathrm{~mm}^{3}$, was then implanted in rabbit (Japanese white, female, $3 \mathrm{~kg}$ ) corneal stroma $\sim 2 \mathrm{~mm}$ away from the corneal-scleral junction as described previously (29). Various concentrations of D-Pen were injected daily intravenously, and the rabbit was killed $8 \mathrm{~d}$ later. Before being killed, the rabbit was perfused from the carotid artery with colloidal carbon to outline the corneal blood vessels. Newly formed blood vessels between the corneal-scleral junction and the ECGF pellet were then macroscopically examined. For histological examination, entire anterior segments (cornea and iris) were excised and fixed with $10 \%$ buffered formalin. Paraffin sections were stained with hematoxylin and eosin.

Measurement of D-Pen concentration in the plasma of rabbits intravenously injected with D-Pen. The rabbits were injected intravenously with $10 \mathrm{mg} / \mathrm{kg}$ D-Pen. Venous blood was taken at various times thereafter and the concentrations of D-Pen in the plasma were determined by HPLC as described previously (30).

\section{Results}

Synergistic inhibition of EC DNA synthesis by D-Pen and copper sulfate. To study the dose response of EC to ECGF and the effect of D-Pen on this response, the monolayers derived from $2 \times 10^{4} \mathrm{EC}$ in microtiter wells were incubated with increasing concentrations of ECGF, simultaneously with or without D-Pen or D-Pen plus copper sulfate (Fig. 1). ECGF increased $\left[{ }^{3} \mathrm{H}\right] \mathrm{TdR}$ incorporation into EC in a dose-dependent fashion. A significant increase was observed at $12.5 \mu \mathrm{g} / \mathrm{ml} \mathrm{ECGF} \mathrm{and}$ maximal response was attained at $50 \mu \mathrm{g} / \mathrm{ml}$. D-Pen, when added at a concentration of $15 \mu \mathrm{g} / \mathrm{ml}(100 \mu \mathrm{M})$ in the presence of $2 \mu \mathrm{g} / \mathrm{ml}(8 \mu \mathrm{M})$ copper sulfate, clearly inhibited $\left[{ }^{3} \mathrm{H}\right] \mathrm{TdR}$ incorporation both into basal and ECGF-stimulated EC. D-Pen, at this concentration, did not significantly affect the DNA synthesis of EC in the absence of copper. The concentration of ECGF, which induced half-maximal response in DNA synthesis, was not significantly affected by D-Pen and copper. Fig. 2 shows the dose-dependent effect of copper sulfate on D-Pen-induced inhibition of $\left[{ }^{3} \mathrm{H}\right] \mathrm{TdR}$ incorporation. Neither $15 \mu \mathrm{g} / \mathrm{ml}$ D-Pen alone nor various concentrations of 


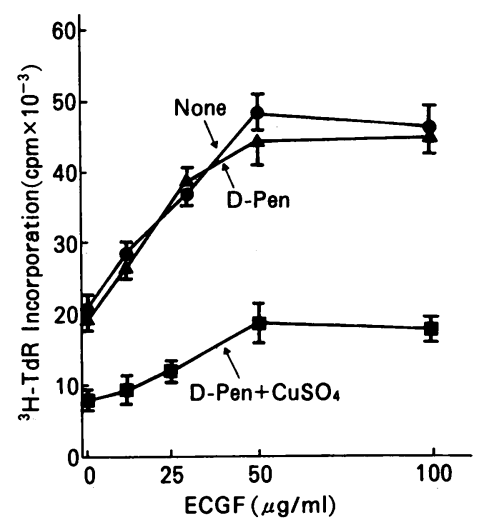

Figure 1. Inhibition of DNA synthesis of EC by D-Pen and copper sulfate. 2 $\times 10^{4}$ cells were incubated with various concentrations of ECGF with or without $15 \mu \mathrm{g} / \mathrm{ml}(100 \mu \mathrm{M}) \mathrm{D}-P e n$ or $15 \mu \mathrm{g} / \mathrm{ml} \mathrm{D}-$ Pen plus 2 $\mu \mathrm{g} / \mathrm{ml}(8 \mu \mathrm{M}) \mathrm{CuSO}_{4}$, and $\left[{ }^{3} \mathrm{H}\right] \mathrm{TdR}$ incorporation was assayed after $48 \mathrm{~h}$. Each value represents the mean $\pm \mathrm{SE}$ of seven separate experiments, each done in triplicate.

copper sulfate alone significantly affected the DNA synthesis of the EC. A strong inhibitory effect, however, was noted in the presence of D-Pen and copper sulfate combined. This inhibition was observed at a concentration of $0.5 \mu \mathrm{g} / \mathrm{ml}$ and increased with the increasing concentrations of copper sulfate.

Comparison of inhibition of EC, fibroblast, and PBMC DNA synthesis by D-Pen and copper sulfate. The dose-dependent inhibitory effects on the DNA synthesis of EC exerted by D-Pen in the presence or absence of copper sulfate have been compared with that exerted on fibroblasts and on lymphocytes in mitogen-stimulated PBMC cultures (Fig. 3). D-Pen and copper inhibited DNA synthesis in both unstimulated and ECGF-stimulated EC in a dose-dependent fashion, with significant inhibition being observed in the range of $10 \mu \mathrm{g} / \mathrm{ml} .15$ $\mu \mathrm{g} / \mathrm{ml}$ D-Pen produced 65 and $60 \%$ inhibition of DNA synthesis in basal and ECGF-stimulated EC cultures, respectively. These ranges of concentrations did not significantly affect EC viability when examined by trypan blue exclusion and ${ }^{51} \mathrm{Cr}$ release. These concentrations are also attained in the serum and synovial tissue of treated patients (31-33). D-Pen, when present in the absence of copper sulfate, induced small but significant inhibition at a level of $25 \mu \mathrm{g} / \mathrm{ml}$. Similar magnitude of inhibition by D-Pen and copper sulfate was observed in the DNA synthesis of both unstimulated and IL 1-stimulated fibroblasts. Inhibition of DNA synthesis of lymphocytes in Con A or PHA-stimulated PBMC cultures was smaller than those observed with $\mathrm{EC}$ and fibroblasts at concentrations $>15 \mu \mathrm{g} / \mathrm{ml}$ $(P<0.05)$.

Effect of $\mathrm{H}_{2} \mathrm{O}_{2}$ and $\mathrm{H}_{2} \mathrm{O}_{2}$ generated by D-Pen and copper sulfate on EC DNA synthesis. As it has been suggested that D-Pen in the presence of cupric ion produces $\mathrm{H}_{2} \mathrm{O}_{2}$ and that the $\mathrm{H}_{2} \mathrm{O}_{2}$ produced plays a significant role in the inhibition of

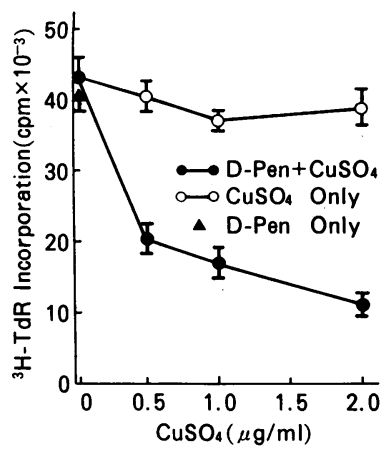

Figure 2. Synergistic action of D-Pen and copper sulfate in the inhibition of EC DNA synthesis. EC were incubated with $50 \mu \mathrm{g} / \mathrm{ml}$ ECGF plus $15 \mu \mathrm{g} / \mathrm{ml}$ D-Pen alone or plus $15 \mu \mathrm{g} / \mathrm{ml} \mathrm{D-Pen} \mathrm{with} \mathrm{and}$ without increasing concentrations of $\mathrm{CuSO}_{4} \cdot\left[{ }^{3} \mathrm{H}\right] \mathrm{TdR}$, incorporated into the cells, was assayed after 48 $h$. Each value is the mean $\pm \mathrm{SE}$ of five separate experiments done in triplicate.

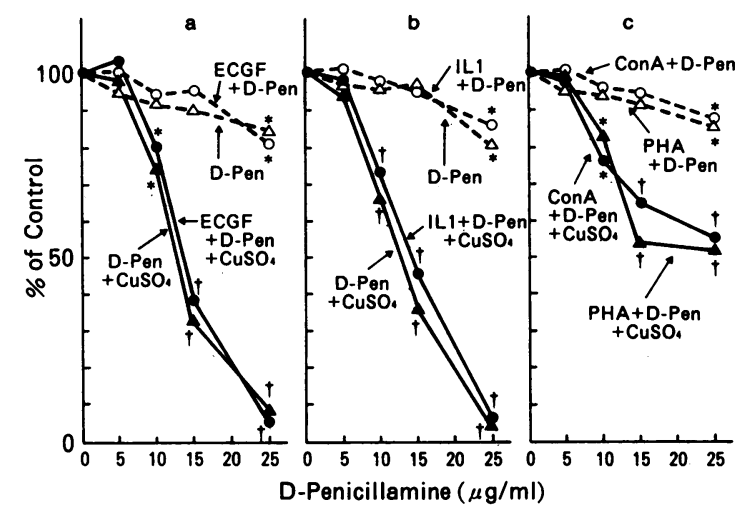

Figure 3. Comparison of inhibition of EC DNA synthesis with that of fibroblasts and PBMC by D-Pen and copper sulfate. $(A)$ EC were cultured with increasing concentrations of D-Pen with or without 50 $\mu \mathrm{g} / \mathrm{ml} \mathrm{ECGF}$ in the presence or absence of $2 \mu \mathrm{g} / \mathrm{ml} \mathrm{CuSO}_{4}$. Total $\left[{ }^{3} \mathrm{H}\right] \mathrm{TdR}$ incorporated in EC cultured only with ECGF $(100 \%$ value, $46,760 \pm 5,330 \mathrm{SE} \mathrm{cpm})$ or without ECGF (100\% value,

$22,430 \pm 2,540 \mathrm{SE} \mathrm{cpm}$ ) were taken as controls. Each point represents the mean of seven separate experiments, each done in triplicate. $(B)$ $1 \times 10^{4}$ fibroblasts were cultured with or without $1 \mathrm{U} / \mathrm{ml}$ ultrapure IL 1 and the indicated concentrations of D-Pen with or without 2 $\mu \mathrm{g} / \mathrm{ml} \mathrm{CuSO}_{4}$. $\left[{ }^{3} \mathrm{H}\right] \mathrm{TdR}$ incorporation was assayed $72 \mathrm{~h}$ after initiation of the assay. Total incorporated $\left[{ }^{3} \mathrm{H}\right] \mathrm{TdR}$ in the cells cultured only with IL $1(100 \%$ value, $50,320 \pm 7,080 \mathrm{SE} \mathrm{cpm})$ or without IL 1 ( $100 \%$ value, $26,740 \pm 4,250 \mathrm{SE} \mathrm{cpm}$ ) were taken as controls. Each point represents the mean of five separate experiments, each done in triplicate. $(C) 1 \times 10^{5}$ PBMC were cultured with $5 \mu \mathrm{g} / \mathrm{ml}$ Con A or $0.5 \mu \mathrm{g} / \mathrm{ml}$ PHA and with increasing concentrations of D-Pen in the presence or absence of $2 \mu \mathrm{g} / \mathrm{ml} \mathrm{CuSO}_{4}$. $\left[{ }^{3} \mathrm{H}\right] \mathrm{TdR}$ incorporation was assayed after $72 \mathrm{~h}$. Total ${ }^{3} \mathrm{H}$-TdR incorporation into PBMC cultured with Con A alone ( $100 \%$ value, $49,830 \pm 5,980 \mathrm{SE} \mathrm{cpm}$ ) or PHA alone $(100 \%$ value, $81,340 \pm 8,690 \mathrm{SE} \mathrm{cpm})$ were taken as controls. $\left[{ }^{3} \mathrm{H}\right] \mathrm{TdR}$ incorporation into PBMC without mitogen stimulation was $980 \pm 540 \mathrm{SE} \mathrm{cpm}$. Each point represents the mean of four separate experiments, each done in triplicate. A $t$ test of each point was performed by comparison with the control $\left({ }^{*}=P<0.05,^{\dagger}=P<0.01\right)$.

the proliferation of $\mathrm{T}$ lymphocytes (22), the effects of $\mathrm{H}_{2} \mathrm{O}_{2}$ on EC DNA synthesis were examined (Fig. 4). When $\mathrm{H}_{2} \mathrm{O}_{2}$ was added to the EC cultures, it inhibited $\left[{ }^{3} \mathrm{H}\right] \mathrm{TdR}$ incorporation into both basal and ECGF-stimulated EC in a dose-dependent

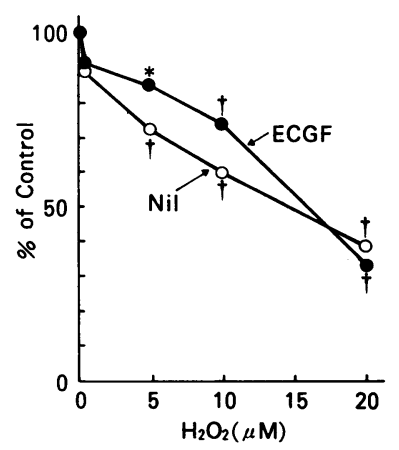

Figure 4. Inhibition of DNA synthesis of EC by hydrogen peroxide. EC were cultured with or without $50 \mu \mathrm{g} / \mathrm{ml}$ ECGF, in the presence of the indicated concentrations of $\mathrm{H}_{2} \mathrm{O}_{2}$. [ $\left.{ }^{3} \mathrm{H}\right] \mathrm{TdR}$ incorporation was assayed after $48 \mathrm{~h}$. $\left[{ }^{3} \mathrm{H}\right] \mathrm{TdR}$ incorporation into EC, cultured only with ECGF (100\% value, $53,420 \pm 6,890 \mathrm{SE} \mathrm{cpm})$ or without ECGF ( $100 \%$ value, $23,540 \pm 2,670 \mathrm{SE} \mathrm{cpm})$, was taken as controls. Each point represents the mean of four separate experiments, each done in triplicate. A $t$ test of each point was done by comparison with the control $\left(^{*}=P<0.05,{ }^{\dagger}=P<0.01\right)$. 
Table I. Inhibition of DNA Synthesis of EC by Hydrogen Peroxide. Prevention of Inhibition by CAT and HRPO But Not by boiled CAT or SOD

\begin{tabular}{lcr}
\hline \multirow{2}{*}{ Agent added } & \multicolumn{2}{c}{$\left[{ }^{3} \mathrm{H}\right]$ TdR incorporation } \\
\cline { 2 - 3 } & $\mathrm{EC}+\mathrm{Nil}$ & $\mathrm{cpm} \times 10^{-3}$ \\
$\mathrm{Nil}$ & \multicolumn{3}{c}{$\mathrm{ECGF}$} \\
$\mathrm{H}_{2} \mathrm{O}_{2}$ & $25.6 \pm 3.1$ & $47.6 \pm 5.1$ \\
$\mathrm{H}_{2} \mathrm{O}_{2}+\mathrm{CAT}$ & $11.3 \pm 1.9$ & $15.2 \pm 2.1$ \\
$\mathrm{H}_{2} \mathrm{O}_{2}+\mathrm{HRPO}$ & $22.8 \pm 3.1$ & $43.6 \pm 5.3$ \\
$\mathrm{H}_{2} \mathrm{O}_{2}+$ Boiled CAT & $21.9 \pm 2.6$ & $42.1 \pm 3.6$ \\
$\mathrm{H}_{2} \mathrm{O}_{2}+$ SOD & $10.9 \pm 2.3$ & $16.9 \pm 2.5$ \\
$\mathrm{CAT}$ & $12.6 \pm 2.1$ & $14.1 \pm 1.8$ \\
$\mathrm{HRPO}$ & $24.3 \pm 1.9$ & $44.8 \pm 3.6$ \\
Boiled CAT & $23.2 \pm 3.6$ & $41.9 \pm 5.6$ \\
SOD & $22.6 \pm 3.2$ & $46.8 \pm 5.0$ \\
\hline
\end{tabular}

EC were cultured with or without $50 \mu \mathrm{g} / \mathrm{ml} \mathrm{ECGF} \mathrm{in} \mathrm{the} \mathrm{absence} \mathrm{or}$ presence of $20 \mu \mathrm{M} \mathrm{H}_{2} \mathrm{O}_{2}$ with or without $500 \mathrm{U} / \mathrm{ml} \mathrm{CAT,} 280 \mathrm{U} / \mathrm{ml}$ HRPO, $500 \mathrm{U} / \mathrm{ml}$ boiled CAT, or $50 \mu \mathrm{g} / \mathrm{ml} \mathrm{SOD.}\left[{ }^{3} \mathrm{H}\right] \mathrm{TdR}$ incorporation was assayed after $48 \mathrm{~h}$. Each value represents the mean $\pm S E$ of three separate experiments, each done in triplicate.

fashion. Significant inhibition was detected at a concentration of $5 \mu \mathrm{M} \mathrm{H}_{2} \mathrm{O}_{2}$ and linear inhibition was observed up to $20 \mu \mathrm{M}$. In this concentration range, $\mathrm{H}_{2} \mathrm{O}_{2}$ did not significantly affect the viability of $\mathrm{EC}$ when examined by both ${ }^{51} \mathrm{Cr}$ release and trypan blue exclusion. Table I showed the effect of CAT, HRPO, boiled CAT, or SOD on the $\mathrm{H}_{2} \mathrm{O}_{2}$-induced inhibition of EC DNA synthesis. Both CAT and HRPO reversed the $\mathrm{H}_{2} \mathrm{O}_{2}$ inhibition. When the enzymatic activity of CAT was blocked by boiling as described previously (27), CAT failed to prevent the inhibition exerted by $\mathrm{H}_{2} \mathrm{O}_{2}$. SOD did not affect the inhibition by $\mathrm{H}_{2} \mathrm{O}_{2}$. These enzymes, when added to the cultures alone, did not alter either basal and ECGF-stimulated EC proliferation.

To determine whether the inhibitory effects of D-Pen and copper sulfate might be due to $\mathrm{H}_{2} \mathrm{O}_{2}$ produced by these agents, the effects of CAT, HRPO, boiled CAT, and SOD on D-Pen and copper sulfate-induced inhibition of EC DNA synthesis were examined (Fig. 5). The addition of CAT or HRPO reversed the inhibition by D-Pen and copper sulfate to the con-

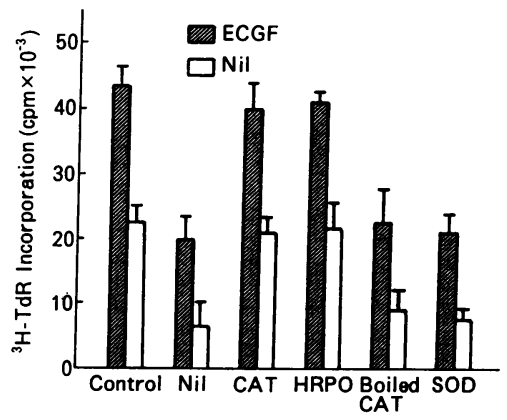

Figure 5. Inhibition of DNA synthesis of EC by D-Pen and copper sulfate. Prevention by CAT or HRPO but not by boiled CAT or SOD. EC were cultured with or without $50 \mu \mathrm{g} / \mathrm{ml}$ ECGF in the presence or absence (control) of $15 \mu \mathrm{g} / \mathrm{ml} \mathrm{D}-P e n$ and 2

$\mu \mathrm{g} / \mathrm{ml} \mathrm{CuSO}_{4}$ plus either nil, $500 \mathrm{U} / \mathrm{ml} \mathrm{CAT,} 280 \mathrm{U} / \mathrm{ml} \mathrm{HRPO}, 500$ $\mathrm{U} / \mathrm{ml}$ boiled CAT, or $50 \mu \mathrm{g} / \mathrm{ml}$ SOD. After $48 \mathrm{~h},\left[{ }^{3} \mathrm{H}\right] \mathrm{TdR}$ incorporation was measured. Each bar is the mean $\pm \mathrm{SE}$ of four separate experiments, each done in triplicate.

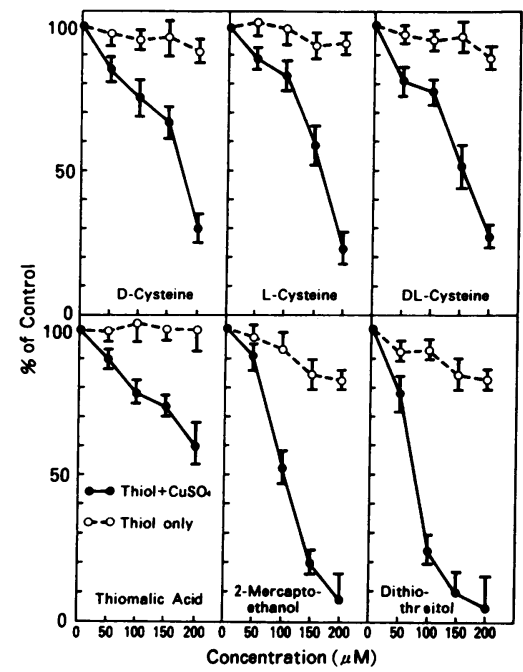

Figure 6. Effect of various thiols on EC DNA synthesis in the presence or absence of copper sulfate. EC were cultured with $50 \mu \mathrm{g} / \mathrm{ml}$ ECGF and the indicated concentrations of various thiols in the presence or absence of 2 $\mu \mathrm{g} / \mathrm{ml} \mathrm{CuSO}_{4} \cdot\left[{ }^{3} \mathrm{H}\right] \mathrm{TdR}$ incorporation was measured after $48 \mathrm{~h}$. Total $\left[{ }^{3} \mathrm{H}\right] \mathrm{TdR}$ incorporation into EC with ECGF (100\% value, $45,890 \pm 5,030 \mathrm{SE} \mathrm{cpm})$ was taken as control. Each point represents the mean $\pm S E$ of three separate experiments, each done in triplicate.

trol level. SOD and boiled CAT, on the contrary, failed to reverse the inhibition.

Effect of other thiols and of disulfides. The possible D-Penlike action of other sulfhydryl compounds in the presence or absence of cupric ion on ECGF-stimulated EC proliferation is shown in Fig. 6. D-Cysteine, L-cysteine, DL-cysteine, thiomalic acid, 2-mercaptoethanol, and DTT in the presence of copper sulfate, inhibited $\left[{ }^{3} \mathrm{H}\right] \mathrm{TdR}$ incorporation into EC in a dosedependent fashion. The inhibition was minimal in the absence of copper sulfate. The effects of two disulfides on EC DNA synthesis were also examined (Fig. 7). Regardless of the presence or absence of copper sulfate, neither D-Pen disulfide nor oxidized glutathione affected EC proliferation. The corresponding thiols, however, were active. Inhibition of EC proliferation induced by the thiols in the presence of copper sulfate was also reversed by addition of CAT or HRPO (Table II).

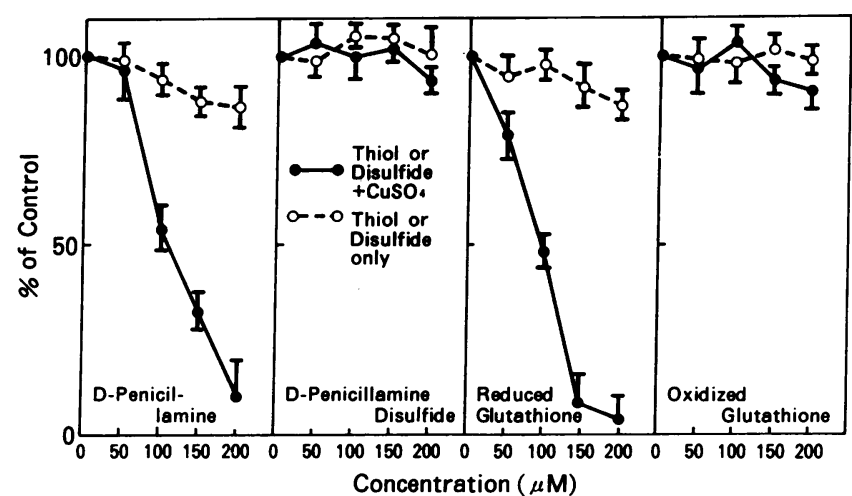

Figure 7. Comparison of effect of disulfides with that of thiols on DNA synthesis of EC in the presence or absence of copper sulfate. EC were cultured with $50 \mu \mathrm{g} / \mathrm{ml} \mathrm{ECGF}$ in the presence or absence of $2 \mu \mathrm{g} / \mathrm{ml} \mathrm{CuSO}_{4}$, and varying concentrations of D-Pen, D-Pen disulfide, reduced glutathione, or oxidized glutathione. After $48 \mathrm{~h},\left[{ }^{3} \mathrm{H}\right]-$ TdR incorporated into the cells was assayed. Total $\left[{ }^{3} \mathrm{H}\right] \mathrm{TdR}$ incorporated into the EC with ECGF ( $100 \%$ value, $49,860 \pm 3,560 \mathrm{SE} \mathrm{cpm}$ ) was taken as control. Each point is the mean $\pm \mathrm{SE}$ of three separate experiments, each done in triplicate. 
Table II. Inhibition of EC DNA Synthesis by Various Thiols in the Presence of Copper Sulfate. Prevention by CAT and HRPO

\begin{tabular}{lrcc}
\hline \multirow{2}{*}{\multicolumn{1}{c}{ Thiols added }} & \multicolumn{3}{c}{$\left[^{3} \mathrm{H}\right] \mathrm{TdR}$ incorporation } \\
\cline { 2 - 4 } \multicolumn{1}{c}{$200 \mu \mathrm{m}$} & \multicolumn{1}{c}{ Nil } & CAT & HRPO \\
& & $c p m \times 10^{-3}$ & \\
Nil & & & \\
D-Penicillamine & $42.6 \pm 4.0$ & $43.5 \pm 3.2$ & $38.8 \pm 3.8$ \\
D-Cysteine & $3.6 \pm 0.9$ & $38.6 \pm 4.5$ & $39.5 \pm 5.2$ \\
L-Cysteine & $13.2 \pm 2.6$ & $40.6 \pm 4.3$ & $35.5 \pm 4.3$ \\
DL-Cysteine & $9.8 \pm 1.6$ & $38.7 \pm 5.6$ & $40.5 \pm 5.1$ \\
Thiomalic acid & $10.5 \pm 1.1$ & $42.6 \pm 4.8$ & $36.5 \pm 4.1$ \\
2-mercaptoethanol & $23.4 \pm 2.9$ & $44.6 \pm 2.8$ & $41.5 \pm 5.6$ \\
cDTT & $3.0 \pm 0.6$ & $37.1 \pm 4.6$ & $34.1 \pm 3.6$ \\
Reduced glutathione & $0.9 \pm 0.3$ & $36.8 \pm 5.1$ & $33.8 \pm 2.9$ \\
& $0.8 \pm 0.4$ & $41.3 \pm 5.6$ & $39.6 \pm 5.8$ \\
\hline
\end{tabular}

EC were cultured with $50 \mu \mathrm{g} / \mathrm{ml} \mathrm{ECGF}$ with or without various thiols, $2 \mu \mathrm{g} / \mathrm{ml} \mathrm{CuSO}_{4}$, and $500 \mathrm{U} / \mathrm{ml} \mathrm{CAT}$, or $280 \mathrm{U} / \mathrm{ml} \mathrm{HRPO}$. Each number is the mean $\pm \mathrm{SE}$ of three separate experiments, each done in triplicate.

Absence of effect of CAT and HRPO on the inhibition of EC DNA synthesis produced by gold sodium thiomalate (GST). Because we have reported that GST inhibited $\left[{ }^{3} \mathrm{H}\right] \mathrm{TdR}$ incorporation into basal and ECGF-stimulated EC (34), and since the ligand of GST is thiomalic acid, which contains a sulfhydryl bond, the effects of copper sulfate, CAT, and HRPO on the action of GST were examined (Fig. 8). When various concentrations of copper sulfate were added to the EC cultures simultaneously with $10 \mu \mathrm{g} / \mathrm{ml}$ GST, there was no significant enhancement of GST-induced inhibition of both basal and ECGF-stimulated EC DNA synthesis. Moreover, the GST-induced inhibition itself was not reversed by CAT or HRPO.

Effect of duration and time of exposure of EC to D-Pen and copper sulfate on EC DNA synthesis. Results of time kinetic studies of the effects of D-Pen and copper sulfate on basal and

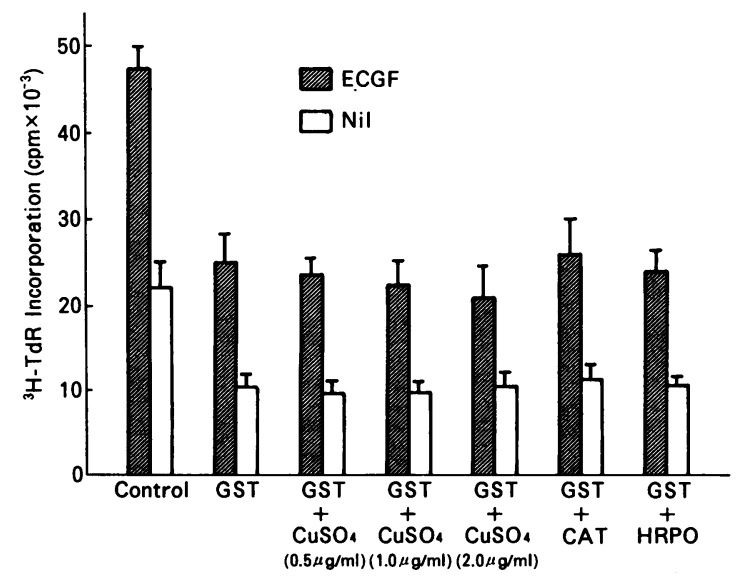

Figure 8. Effect of copper sulfate on GST-induced inhibition of EC DNA synthesis. No prevention of GST-induced inhibition by CAT or HRPO. EC were cultured with or without $50 \mu \mathrm{g} / \mathrm{ml} \mathrm{ECGF} \mathrm{in} \mathrm{the}$ presence or absence of $10 \mu \mathrm{g} / \mathrm{ml}$ GST. Simultaneously various concentrations of $\mathrm{CuSO}_{4}, 500 \mathrm{U} / \mathrm{ml} \mathrm{CAT}$, or $280 \mathrm{U} / \mathrm{ml} \mathrm{HRPO}$ were added to the cultures. $\left[{ }^{3} \mathrm{H}\right] \mathrm{TdR}$ incorporation was measured after 48 $h$. Each bar represents the mean $\pm S E$ of five separate experiments, each done in triplicate.

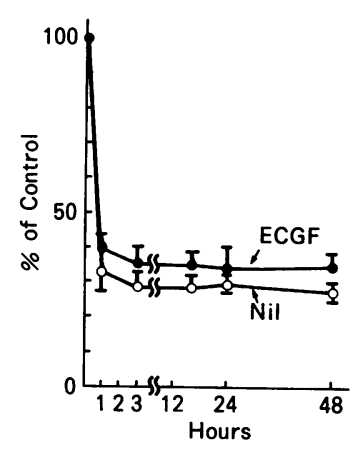

Figure 9. Effect of duration of exposure of EC to D-Pen and copper sulfate on EC DNA synthesis. EC were cultured with or without $50 \mu \mathrm{g} / \mathrm{ml}$ ECGF, and with $15 \mu \mathrm{g} / \mathrm{ml} \mathrm{D-Pen}$ and $2 \mu \mathrm{g} / \mathrm{ml} \mathrm{CuSO}_{4}$ for the indicated time intervals from the initiation of the assay. At the end of these intervals, the added agents were removed, the EC were washed and recultured with or without ECGF until the termination of the assay, and incorporated $\left[{ }^{3} \mathrm{H}\right] \mathrm{TdR}$ was measured. EC cultured only with ECGF ( $100 \%$ value,

$44,680 \pm 5,670 \mathrm{SE} \mathrm{cpm})$ or without ECGF (100\% value, $23,570 \pm 3,420 \mathrm{SE}$ cpm) were taken as controls. Each point represents the mean $\pm \mathrm{SE}$ of four separate experiments, each done in triplicate.

ECGF-induced $\left[{ }^{3} \mathrm{H}\right] \mathrm{TdR}$ incorporation in EC are shown in Fig. 9. EC were cultured with or without ECGF, in the presence or absence of D-Pen and copper sulfate, for 0-48 h. At varying time periods, the supernatant was removed, the EC were washed and then cultured as before with or without fresh ECGF. When D-Pen and copper were present for as little as the initial $1 \mathrm{~h}$, near maximal inhibition of EC DNA synthesis was observed.

DNA synthesis in the course of EC proliferation, as assayed by $\left[{ }^{3} \mathrm{H}\right] \mathrm{TdR}$ incorporation, is a late occurrence in a series of reactions. To determine whether a particular step in these series was sensitive to D-Pen and copper, these agents were added to ECGF-stimulated EC cultures at the initiation of incubation or at varying times thereafter. As shown in Table III, D-Pen and copper sulfate added $15 \mathrm{~h}$ before termination of the assay no longer had a significant effect on the subsequent incorporation of $\left[{ }^{3} \mathrm{H}\right] \mathrm{TdR}$. It is, therefore, suggested that the effects of these agents are exerted in the comparatively early stages of the EC proliferative response.

Table III. Time-dependent Effect of Delayed Addition of D-Pen and Copper Sulfate on DNA Synthesis of EC

\begin{tabular}{lccc}
\hline & & \multicolumn{2}{c}{$\left[{ }^{3} \mathrm{H}\right] \mathrm{TdR}$ incorporation } \\
\cline { 3 - 4 } \multicolumn{1}{c}{ Agent added } & \multicolumn{1}{c}{$\begin{array}{c}\text { Time of } \\
\text { addition }\end{array}$} & Experiment 1 & Experiment 2 \\
\hline & $h$ & \multicolumn{2}{c}{$c p m \times 10^{-3}$} \\
Nil & & 46.5 & 39.6 \\
D-Pen $+\mathrm{CuSO}_{4}$ & 0 & 14.4 & 16.2 \\
Nil & & 41.8 & 42.6 \\
D-Pen $+\mathrm{CuSO}_{4}$ & 12 & 23.7 & 17.8 \\
Nil & & 38.9 & 45.6 \\
D-Pen $+\mathrm{CuSO}_{4}$ & 24 & 25.8 & 35.5 \\
Nil & & 44.8 & 40.8 \\
D-Pen $+\mathrm{CuSO}_{4}$ & 33 & 42.5 & 37.6 \\
\hline
\end{tabular}

EC were cultured in the presence of $50 \mu \mathrm{g} / \mathrm{ml} \mathrm{ECGF,} \mathrm{and} 15 \mu \mathrm{g} / \mathrm{ml}$ D-Pen and $2 \mu \mathrm{g} / \mathrm{ml} \mathrm{CuSO}_{4}$ or culture medium alone were added to the cultures at the initiation of incubation (zero time) or at varying times thereafter. $\left[{ }^{3} \mathrm{H}\right] \mathrm{TdR}$ incorporation was assayed after $48 \mathrm{~h}$. The numbers represent the mean of triplicate measurements. 
Effect of D-Pen on neovascularization in rabbit eye. When an ECGF pellet was implanted in the corneal stroma, growth of the blood vessels began at the corneal-scleral junction. The rate of growth was $\sim 0.25-0.3 \mathrm{~mm} / \mathrm{d}$ in the absence of D-Pen administration until the tips of the vessels reached the pellet. As shown in Fig. 10, there was no infiltration of inflammatory cells around the proliferating blood vessels in the stroma, indicating that the induction of new blood vessels was due to ECGF and not secondary to foreign body reaction to the hydroxyethylmethacrylate pellet. Comparison of the neovascularization induced by an ECGF-containing pellet with that induced by a pellet of hydroxyethylmethacrylate alone, and the effect of D-Pen on the ECGF-induced neovascularization is shown in Fig. 11. Almost no blood vessels sprouted towards the pellet of hydroxyethylmethacrylate alone. D-Pen inhibited both the length and number of vessels growing toward the ECGF pellet and injection of $1 \mathrm{mg} / \mathrm{kg}$ D-Pen caused almost maximal inhibition of vessel growth.

Plasma levels of D-Pen in rabbit. To examine time kinetics of concentrations of D-Pen, $10 \mathrm{mg} / \mathrm{kg}$ D-Pen was injected intravenously and plasma concentrations were measured after various time intervals (Table IV). The concentrations decreased to $<10 \mu \mathrm{g} / \mathrm{ml}$, the effective level in the culture experiment, $30 \mathrm{~min}$ after the injection and reached to nearly $1 \mu \mathrm{g} / \mathrm{ml}$ after $2 \mathrm{~h}$. It is, therefore, indicated that this drug has a rapid turnover in the blood. It is also consistent with this data that near maximal inhibition of EC proliferation was observed in vitro when this drug was present for the initial $1 \mathrm{~h}$ of the culture.

\section{Discussion}

D-Pen has been used for the treatment of RA patients with beneficial effect. A variety of possible mechanisms underlying its effect have been reported, e.g., an antiinflammatory action (14), dissociation of macroglobulins $(15,16)$, interference with leukocyte chemotaxis (17), interference with helper $T$ cell function (18), inhibition of cross-linking of collagen (19), and an SOD-like action $(20,21)$. Recently, it has been reported that this agent may synthesize $\mathrm{H}_{2} \mathrm{O}_{2}$ in the presence of copper and that the inhibition of $\mathrm{T}$ cell function may be exerted by the $\mathrm{H}_{2} \mathrm{O}_{2}$ generated (22). Production of $\mathrm{H}_{2} \mathrm{O}_{2}$ by D-Pen in the presence of cupric ion has been observed in a cell-free system (35).

These data demonstrate that D-Pen inhibited EC proliferation and this inhibition was synergistically enhanced by the presence of the cupric ion. Cupric ion itself, however, did not affect $\left[{ }^{3} \mathrm{H}\right] \mathrm{TdR}$ incorporation into EC. The inhibition by D-Pen in the presence of copper sulfate occurred in a dose-dependent fashion with significant inhibition obtained at the

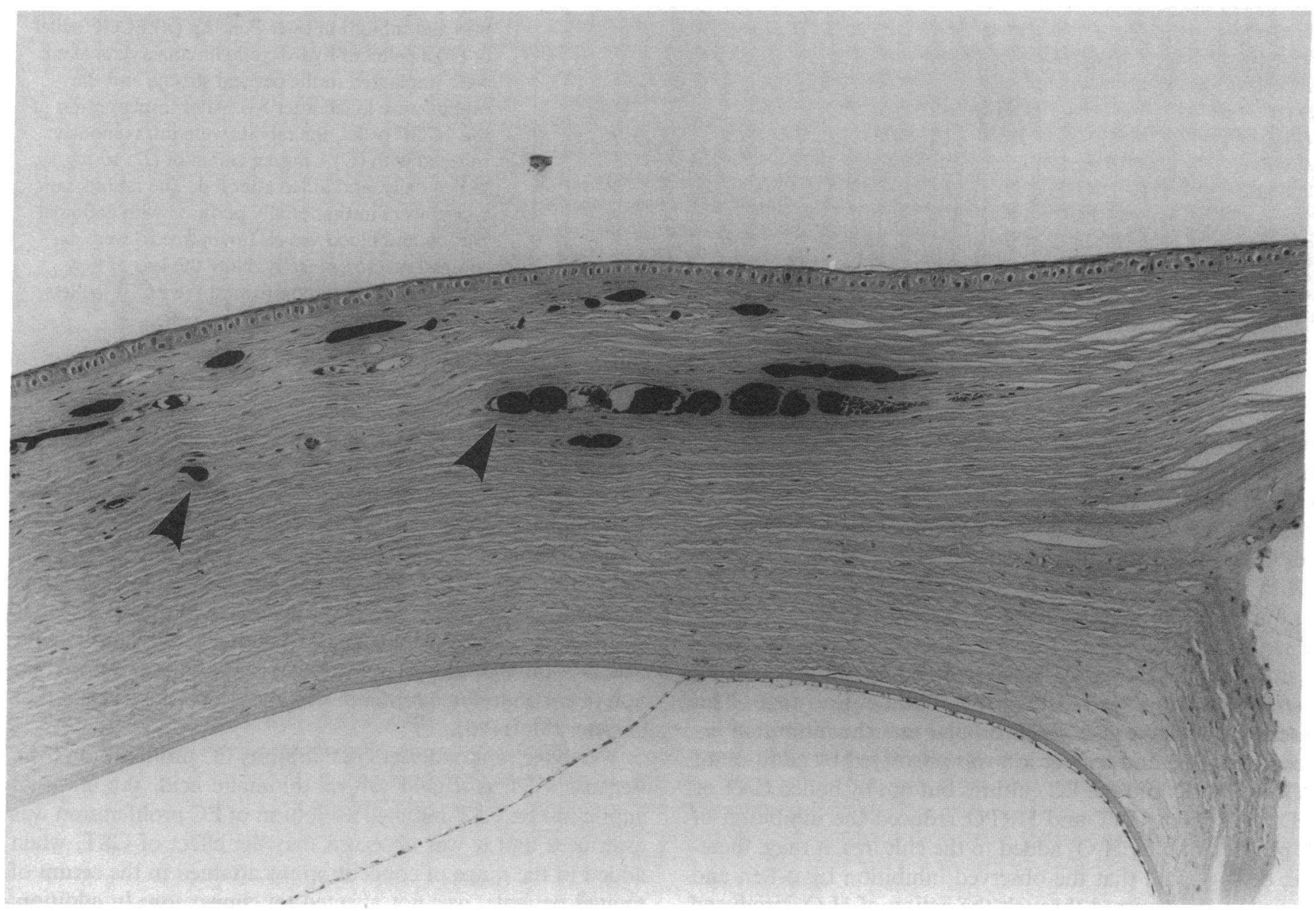

Figure 10. Histologic appearance of the neovascularization process in the corneal stroma. Hydroxyethylmethacrylate pellets with ECGF were implanted in the corneal stroma. A number of new blood vessels are seen (arrowheads) in the stroma with no inflammatory cell infiltration around the vessels (hematoxylin and eosin staining). $\times 40$. 

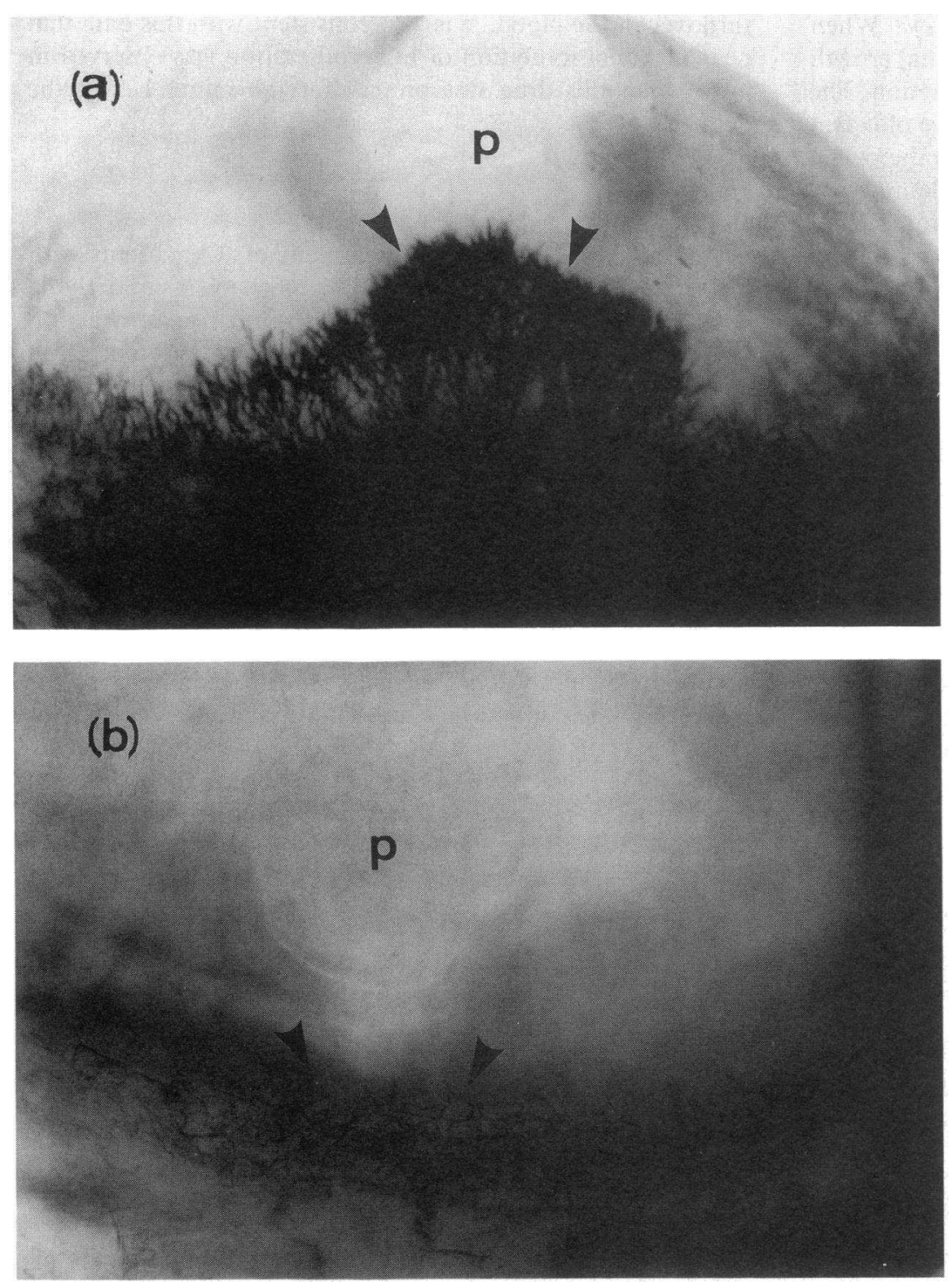

Figure 11. ECGF-induced corneal neovascularization and inhibition by D-Pen. An $(A)$ ECGF pellet or $(B)$ a pellet of hydroxyethylmethacrylate alone were implanted in the corneal stroma and the rabbits were killed after $8 \mathrm{~d}$. After implantation of the ECGF pellet, the rabbits were intravenously injected with $(C) 1 \mathrm{mg} / \mathrm{kg}$ D-Pen or $(D) 10 \mathrm{mg} / \mathrm{kg}$ D-Pen daily, and killed after $8 \mathrm{~d}$. The rabbits sacrificed were intraarterially perfused with colloidal carbon and blood vessels (arrowheads) were examined macroscopically. Note the loss of new blood vessel formation toward the ECGF pellets in the D-Pen-treated rabbits. $p$, pellet. level of $10 \mu \mathrm{g} / \mathrm{ml}$. It has been reported that the range of concentration of this drug in the serum of treated patients ranges up to $20 \mu \mathrm{g} / \mathrm{ml}(31,32)$ and that its tissue concentration is higher because it accumulates in collagen or other joint structures (33). In addition, the maximal concentration of copper used in these experiments, $2 \mu \mathrm{g} / \mathrm{ml}$, was approximately half that found in normal serum and much less than that found in the serum of RA patients (36-39). It appears, therefore, that the observed inhibition by D-Pen and copper ion is occurring at concentrations well within the therapeutic range. The present results have also demonstrated that the inhibition induced by D-Pen and copper ion was prevented by addition of CAT or HRPO into the EC cultures but not by boiled CAT or SOD. Moreover, CAT and HRPO reduced the inhibition of EC proliferation by $\mathrm{H}_{2} \mathrm{O}_{2}$ added to the cultures. It may, therefore, be suggested that the observed inhibition by D-Pen and cupric ion is expressed through the action of $\mathrm{H}_{2} \mathrm{O}_{2}$ produced by these two agents. This is also consistent with previous findings that $\mathrm{H}_{2} \mathrm{O}_{2}$ suppresses the functions of $\mathrm{T}(18,22)$ and natural killer cells (27).
The observations that a variety of thiols blocked EC proliferation in the presence of copper and that this inhibition was also reversed by the addition of CAT or HRPO to the cultures indicate that $\mathrm{H}_{2} \mathrm{O}_{2}$ is a common product in the reaction of all of these agents with copper. As shown in experimental models and in RA patients $(40,41)$, the greater efficacy of D-Pen compared with other thiols, in vivo, may be based on the fact that this drug is resistant to enzymatic degradation by amino acid oxidases and cysteine desulfhydrases (42) and that autooxidation of D-Pen to the internal disulfide is much slower than that of other thiols (43).

We have reported that GST inhibits EC proliferation (34). Because GST is a gold salt of thiomalic acid, the effect of cupric ion on GST-induced inhibition of EC proliferation was examined and it was observed that the effect of GST, when added in the range of concentrations attained in the serum of treated patients, was not affected by copper ion. In addition, the action of GST was not affected by addition of either CAT or HRPO, indicating that GST-induced inhibition was not exerted through the agency of $\mathrm{H}_{2} \mathrm{O}_{2}$. 

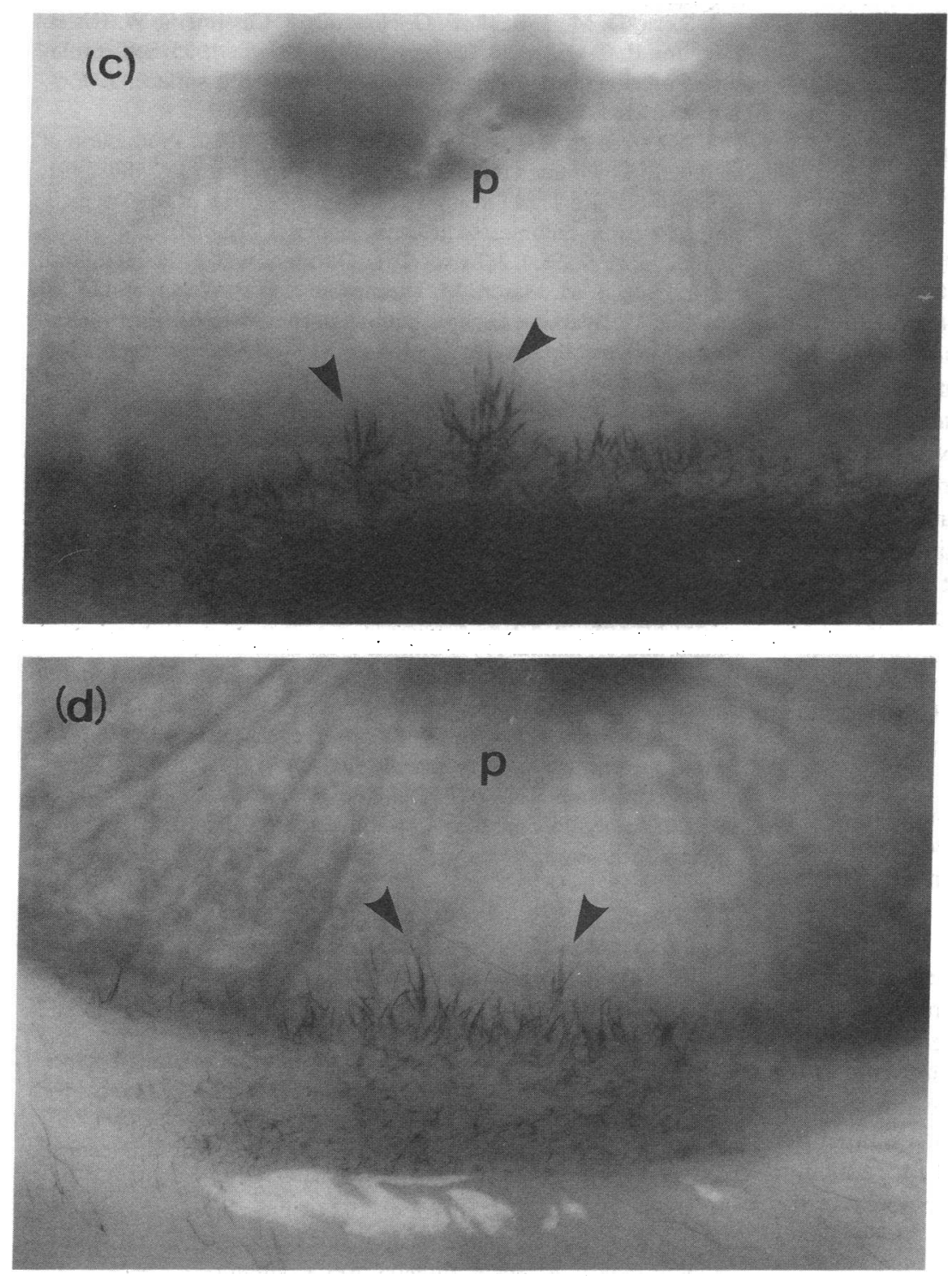

Figure 11 (Continued)

The mechanism whereby $\mathrm{H}_{2} \mathrm{O}_{2}$, produced by D-Pen and cupric ion, inhibits EC proliferation is unresolved at this time. It is unlikely that the observed effect of this agent is due to interference with the binding of ECGF or to a decrease of EC surface receptors for ECGF. This is suggested by the finding that the concentration of ECGF required for the induction of half maximal EC response was not affected by increasing concentrations of D-Pen (data not shown). This suggestion is also supported by the observation that inhibition of EC proliferation was also observed in unstimulated EC treated with D-Pen and copper.

Numerous factors have been reported to support the process of neovascularization. Heparin, a product of mast cells, which can bind ECGF $(44,45)$, has been found to enhance the affinity of this agent for its EC surface receptor (46). Leukocytic infiltration has been observed to precede vascularization in the cornea (47), agents present in supernatants of cultured macrophages (48) and activated macrophages themselves have been observed to stimulate neovascularization (49). IFN- $\gamma$, produced by activated T cells, and IL 1 , a product of macro- phages, have also been suggested to play a role in the induction of angiogenesis by increasing the release of superoxide anion from EC(50). Fibronectin, which is secreted by fibroblasts, has

Table IV. Kinetics of D-Pen Concentration in Rabbit Plasma

\begin{tabular}{|c|c|c|}
\hline \multirow[b]{2}{*}{ Time } & \multicolumn{2}{|c|}{ D-Pen } \\
\hline & Experiment 1 & Experiment 2 \\
\hline $\min$ & \multicolumn{2}{|c|}{$\mu g / m l$} \\
\hline 5 & 34.66 & 29.74 \\
\hline 15 & 18.60 & 15.65 \\
\hline 30 & 9.69 & 7.51 \\
\hline 60 & 4.20 & 2.69 \\
\hline 120 & 1.38 & 0.85 \\
\hline
\end{tabular}

Rabbits were injected with $10 \mathrm{mg} / \mathrm{kg}$ i.v. D-Pen. Blood samples were taken after various time intervals and the D-Pen concentration in the plasma was measured. 
been observed to be a chemoattractant for EC (51). These observations suggest that products of chronic inflammatory cells and fibroblasts may be intimately associated with angiogenesis in chronically inflamed tissue such as the rheumatoid synovium. They are also consistent with the finding that increased vascularity is observed in the transitional areas of RA synovium, in which a mixture of interacting cell types (lymphocytes, macrophages, fibroblasts, and plasma cells) is present (52). In the present experiments, we have demonstrated that D-Pen inhibits ECGF-induced neovascularization in vivo, and the concentration of this drug required for this inhibition was within the range achieved in the serum of treated RA patients $(31,32)$. The above observations together suggest that D-Pen inhibits neovascularization in vivo through suppression of EC proliferation induced by a variety of cytokines and growth factors secreted in inflammatory foci of rheumatoid synovium. The exact focus of the action of D-Pen on in vivo neovascularization in rabbit eye is not clear. However, as there was no histological evidence of leukocytic or mononuclear cell infiltration around the newly grown small blood vessels in the eye, and since D-Pen has a direct inhibitory effect on EC DNA synthesis in vitro, it appears likely that the inhibition of neovascularization resulted from an action on the EC themselves.

In conclusion, $\mathrm{H}_{2} \mathrm{O}_{2}$ produced by physiological concentrations of D-Pen in the presence of copper inhibited both basal and ECGF-stimulated DNA synthesis in human EC. D-Pen also inhibited ECGF-induced neovascularization in vivo. The action of this drug may play a significant role in the suppression of rheumatoid inflammation, since a decrease of the number of local blood vessels may lead to diminished mononuclear cell infiltration and decreased proliferation of the synovial tissue. It may also interfere with the accessory cell activity of the EC at the blood tissue interface. Because EC are not replenished from other sources, the delay in onset of the therapeutic effect of D-Pen may represent the time required for reducing the vascular beds in synovial inflammatory foci below a critical level.

\section{Acknowledgments}

We wish to thank Carol Matsubara for her help in the preparation of the final manuscript.

\section{References}

1. Folkman, J. 1985. Tumor angiogenesis. Adv. Cancer Res. 43:175-203.

2. Zvaifler, N. J. 1973. The immunopathology of joint inflammation in rheumatoid arthritis. Adv. Immunol. 16:265-336.

3. Hirshberg, H., O. J. Bergh, and E. Throsby. 1980. Antigenpresenting properties of human vascular endothelial cells. J. Exp. Med. 152:249s-255s.

4. Burger, D. R., D. Ford, R. M. Vetto, A. Hamblin, A. Goldstein, M. Hubbard, and D. Dumonde. 1981. Endothelial cell presentation of antigen to human T cells. Human Immunol. 3:209-230.

5. Ashida, E. R., A. R. Johnson, and P. E. Lipsky. 1981. Human endothelial cells-lymphocyte interaction. Endothelial cells function as accessory cells necessary for mitogen-induced human $\mathrm{T}$ lymphocytes activation in vitro. J. Clin. Invest. 67:1490-1499.

6. Pober, J. S., M. A. Gimbrone, Jr., R. S. Cotran, C. S. Reiss, S. J. Burakoff, W. Fiers, and K. A. Ault. 1983. Ia expression by vascular endothelium is induced by activated $T$ cells and by human $\gamma$-interferon. J. Exp. Med. 157:1339-1353.
7. Stern, D. M., I. Bank, P. O. Nawroth, J. Cassimeris, W. Kisiel, W. Fenton II, C. Dinarello, L. Chess, and E. A. Jaffe. 1985. Self-regulation of procoagulant events on the endothelial cell surface. J. Exp. Med. 162:1223-1235.

8. Miossec, P., D. E. Cavender, and M. Ziff. 1986. Production of interleukin 1 by human endothelial cells. J. Immunol. 136:2486-2491.

9. Multicentre Trial Group. 1973. Controlled trial of D(-)-penicillamine in severe rheumatoid arthritis. Lancet. i:275-280.

10. Dixon, A., St. J. J. Davis, T. L. Dormandy, E. B. D. Hamilton, P. J. L. Holt, R. M. Mason, M. Thompson, J. C. P. Weber, and D. W. Zutshi. 1975. Synthetic D-penicillamine in rheumatoid arthritis. Double blind controlled study of high and low dosage regimen. Ann. Rheum. Dis. 34:416-421.

11. Berry, H., S. P. Liyanage, R. A. Durance, C. G. Barnes, L. A. Berger, and S. Evans. 1976. Azathioprine and penicillamine in treatment of rheumatoid arthritis: a controlled trial. Br. Med. J. 1:10521054.

12. Mery, C., F. Delrieu, R. Ghozlan, L. Saporta, F. Simon, B. Amor, C. J. Menkes, and F. Delbarre. 1976. Controlled trial of D-penicillamin in rheumatoid arthritis. Scand. J. Rheumatol. 5:241-247.

13. Shiokawa, Y., Y. Horiuchi, M. Honma, T. Kageyama, T. Okada, and T. Azuma. 1977. Clinical evaluation of D-penicillamine by multicentric double-blind comparative study in chronic rheumatoid arthritis. Arthritis Rheum. 20:1464-1472.

14. Sorenson, J. R. J. 1976. Copper chelates as possible active forms of the antiarthritic agents. J. Med. Chem. 19:135-148.

15. Ritzmann, S. E., S. L. Coleman, and W. C. Levin. 1960. The effect of some mercaptanes upon a macrocryogelglobulin. Modifications induced by cysteamine, penicillamine, and penicillin. J. Clin. Invest. 39:1320-1329.

16. Jaffe, I. 1962. Intra-articular dissociation of rheumatoid factor. J. Lab. Clin. Med. 60:409-421.

17. Chwalinska-Sadowska, H., and J. Baum. 1976. The effect of D-penicillamine on polymorphonuclear function. J. Clin. Invest. 58:871-879.

18. Lipsky, P. E., and M. Ziff. 1980. Inhibition of human helper T cell function in vitro by D-penicillamine and $\mathrm{CuSO}_{4} . \mathrm{J}$. Clin. Invest. 65:1069-1076.

19. Siegel, R. C. 1977. Collagen crosslinking: effect of D-penicillamine on crosslinking in vitro. J. Biol. Chem. 252:254-259.

20. Younes, M., and U. Weser. 1977. Superoxide dismutase activity of copper-penicillamine: possible involvement of $\mathrm{Cu}$ (I) stabilized sulphur radical. Biochem. Biophys. Res. Commun. 78:1247-1253.

21. Lengfelder, E., and E. F. Elstner. 1978. Determination of the superoxide dismutating activity of D-penicillamine copper. HoppeSeyler's Z. Physiol. Chem. 359:751-757.

22. Lipsky, P. E. 1984. Immunosuppression by D-penicillamine in vitro. Inhibition of human $T$ lymphocyte proliferation by copper- or ceruloplasm-independent generation of hydrogen peroxide and protection by monocytes. J. Clin. Invest. 73:53-65.

23. Jaffe, E. A., R. L. Nachman, C. G. Becker, and C. R. Minick. 1973. Culture of human endothelial cells derived from umbilical veins. J. Clin. Invest. 52:2745-2756.

24. Nunez, G. V., V. Ugolini, J. D. Capra, and P. Stastny. 1982. Monoclonal antibodies against human monocytes. II. Recognition of two distinct cell surface molecules. Scand. J. Immunol. 16:515-523.

25. Schmidt, J. A., S. B. Mizel, D. Cohen, and I. Green. 1982. Interleukin 1, a potential regulator of fibroblast proliferation. J. Immunol. 128:2177-2182.

26. Boyum, A. 1968. Isolation of mononuclear cells and granulocytes from human blood. Isolation of mononuclear cells by one centrifugation, and of granulocytes by combining centrifugation and sedimentation at 1 g. Scand. J. Clin. Lab. Invest. (Suppl.) 21:77-89.

27. Seaman, W. E., T. D. Gindhart, M. A. Blackman, B. Dalal, N. Talal, and Z. Werb. 1982. Suppression of natural killing in vitro by monocytes and polymorphonuclear leukocytes. Requirement for reactive metabolites of oxygen. J. Clin. Invest. 69:876-888.

28. Langer, R., and J. Folkman. 1976. Polymers for the sustained 
release of proteins and other macromolecules. Nature (Lond.). 263:797-800.

29. Gimbrone, M. A., Jr., R. S. Cotran, S. B. Leapman, and J. Folkman. 1974. Tumor growth and neovascularization: an experimental model using the rabbit cornea. J. Natl. Cancer Inst. 52:413-427.

30. Kukovetz, W. R., E. Beubler, F. Kreuzig, A. J. Moritz, G. Nirnberger, and L. Wener-Breitenecker. 1983. Bioavailability and pharmacokinetics of D-penicillamine. J. Rheumatol. 10:90-94.

31. Muijsers, A. O., R. J. Van de Stadt, A. M. A. Henrichs, and J. K. Van der Korst. 1979. Determination of D-penicillamine in serum and urine of patients with rheumatoid arthritis. Clin. Chim. Acta. 94:173-180.

32. Van de Stadt, R. J., A. O. Muijsers, A. M. A. Henrichs, and J. K. Van der Korst. 1979. D-penicillamine. Biochemical, metabolic and pharmacological aspects. Scand. J. Rheumatol. (Suppl.) 28:13-20.

33. Ruis-Torres, V. A. 1974. Zur Pharmakokinetik und Zum Stoffwechsel von D- und L-penicillamin. I. Mitteilung: Blutspiegel, Transport und Eiweisbindung. Arzneim-Forsch. 24:941-950.

34. Matsubara, T., and M. Ziff. 1987. Inhibition of human endothelial cell proliferation by gold compounds. J. Clin. Invest. 79:14401446.

35. Starkbaum, G., and R. K. Root. 1985. D-penicillamine: analysis of the mechanism of copper-catalyzed hydrogen peroxide generation. J. Immunol. 134:3317-3378.

36. Scudder, P. R., D. Al-Timini, W. McMurry, A. G. White, B. C. Zoob, and T. L. Dormundy. 1978. Serum copper and related variables in rheumatoid arthritis. Ann. Rheum. Dis. 37:67-70.

37. Aaseth, J., E. Munthe, O. Forre, and E. Steinners. 1978. Trace elements in serum and urine of patients with rheumatoid arthritis. Scand. J. Rheumatol. 7:237-240.

38. Scudder, P. R., W. McMurry, A. G. White, and T. L. Dormandy. 1978. Synovial fluid copper and related variables in rheumatoid and degenerative arthritis. Ann. Rheum. Dis. 37:71-72.

39. White, A. G., P. Scudder, T. L. Dormandy, and V. M. Martin. 1978. Copper: an index of erosive activity? Rheumatol. Rehabil. 17:3-5.

40. Klamer, B., E. T. Kimura, and M. Maksteinieks. 1968. Effects of oral cysteine, penicillamine and $\mathrm{N}$-acetyl-penicillamine on adjuvant arthritis in rats. Pharmacol. Clin. 1:283-288.
41. Jaffe, I. A., and P. Merryman. 1968. Effect of increased serum sulfhydryl content on titre of rheumatoid factor. Ann. Rheum. Dis. 27:14-18.

42. Aphosian, H. V., and L. S. Bradham. 1959. Metabolism in vitro of the sulphydryl amino acids, L- and D-penicillamine. Biochem. Pharmacol. 3:38-47.

43. Jellum, E., and S. Skrede. 1976. Biological aspects of thiol-disulfide reactions during treatment with penicillamine. In Penicillamine Research in Rheumatoid Disease. E. Munthe, editor. Fabritius and Sonner, Oslo. 68-77.

44. Maciag, T., T. Mehiman, R. Friesel, and A. B. Schreiber. 1984. Heparin binds endothelial cell growth factor, the principal endothelial cell mitogen in bovine brain. Science (Wash. DC). 225:932-935.

45. Klagsbrun, M., and Y. Shing. 1984. Heparin affinity of growth factors that stimulate endothelial cell proliferation. Fed. Proc. 43:521. (Abstr.)

46. Schreiber, A. B., J. Kenney, W. J. Kowalski, R. Friesel, T. Mehlman, and T. Maciag. 1985. Interaction of endothelial cell growth factor with heparin: characterization by receptor and antibody recognition. Proc. Natl. Acad. Sci. USA. 82:6138-6142.

47. Fromer, C. H., and K. K. Gordon. 1975. An evaluation of the role of leukocytes in the pathogenesis of experimentally induced corneal vascularization. I. Comparison of experimental methods of corneal vascularization. Am. J. Pathol. 79:537-554.

48. Martin, B. M., M. A. Gimbrone, Jr., E. R. Unanue, and R. S. Cotran. 1981. Stimulation of nonlymphoid mesenchymal cell proliferation by a macrophage-derived growth factor. J. Immunol. 126:15101515.

49. Polvernin, P. J., R. S. Cotran, M. A. Gimbrone, Jr., and E. R. Unanue. 1977. Activated macrophages induce vascular proliferation. Nature (Lond.). 269:804-806.

50. Matsubara, T., and M. Ziff. 1986. Increased superoxide anion release from human endothelial cells in response to cytokines. J. Immunol. 137:3295-3298.

51. Bowersox, J. C., and N. Sorgente. 1973. Chemotaxis of aortic endothelial cells in response to fibronectin. Cancer Res. 42:2547-2551.

52. Kobayashi, I., and M. Ziff. 1973. Electron microscopic studies of lymphoid cells in the rheumatoid synovial membrane. Arthritis Rheum. 16:471-486. 